\title{
PEMBELAJARAN TARI JEPEN DAPAT MENINGKATKAN KECERDASAN KINESTETIK PADA ANAK USIA 5-6 TAHUN DI KELOMPOK BERMAIN DARUSSAKINAH O2 TENGGARONG SEBERANG TAHUN AJARAN 2016 / 2017
}

\author{
Arbibah \\ PG PAUD FKIF Universitas Widya Gama Mahakam Samarinda \\ (Arbibah20@gmail.com) \\ Mahkamah Brantasari \\ PG PAUD FKIF Universitas Widya Gama Mahakam Samarinda \\ (brantasari@gmail.com) \\ Ratna Khairunnisa \\ PG PAUD FKIF Universitas Widya Gama Mahakam Samarinda \\ (nhananisa@gmail.com)
}

\begin{abstract}
Abstrac
This study aims to improve students' Kinestetik intelegence through basic movement of jepen dance,i.e : Butterfly dance for 5-6 year old in Darussakinah 02 Playgroup Tenggarong Seberang. Therefore, The researcher conducted a classroom actionresearch to improve the quality of achievenment. In each cycle, the researcher applied four stages; planning, implementation, observation, andreflection. In this study, the researcher employed two cycles with four meetings in each eycle. Moreover, the observed aspects in this study were coordination among body movement, eyes, hands, and legs, strength, agility and balance.

This research was conducted in Darussakinah 02 Playgroup Tenggarong Seberang on February 2017. The researcher involved ten 5-6 year old students of Darussakinah 02 Playgroup as the research subjects, consisting five males dan five femals. To gather the data, the researcher employed technique, documentation and performance test.

Having analyzed the data, it is found that, in cycle 1, 50,7 \% students were active in responding the lesson for preparing the basic movementof dance. Meanwhile, at cycle 2, $80,5 \%$ students managed to do the dance movement. Considering the increasing percentage in cycle 2 compared with cycle 1 , it can be said that student experienced progress. In brief, students' kinesthetic intelligence was successfully improved through the implementation of Jepen Dance From Kutai, which has been recreated into Buterfly Jepen Dance and Performed in group.
\end{abstract}

Key Words : Kinestetik intelegence, Jepen Dance

\section{PENDAHULUAN}

Masa usia dini atau usia $0-6$ tahun adalah masa keemasan bagi anak, yaitu merupakan usia kritis sekaligus strategis dalam proses pendidikan, yang dapat mempengaruhi proses serta hasil pendidikan pada tahap selanjutnya, Masa ini merupakan masa yang tepat untuk meletakan dasar - dasar pengembangan kemampuan fisik, bahasa, sosial, emosional, seni, moral, dan nilai - nilai agama. Pada masa ini pula dapat mengembangkan kecerdasan yang dimiliki anak melalui rangsangan yang diberikan.

Sujiono dan sujiono menguraikan cara menstimulasi kecerdasan kinestetik atau kecerdasan fisik anak yaitu salah satunya dengan menari . Anak - anak pada 
dasarnya menyukai musik dan tari, untuk melatih kecerdasan kinestetik anak dapat dilakukan dengan mengajak anak menari bersama karena menari menuntut keseimbangan, keselarasan gerak tubuh, kekuatan, dan kelenturan otot.

Untuk anak usia 4 tahun bisa mengatur agar tetap teratur pada irama dengan bertepuk tangan atau tongkat irama, dan anak usia 5 tahun telah belajar bergerak mengiringi musik dengan gerakan yang lebih mulus, lebih halus, dan berirama (Carol Seefldt, 2008 : 300 ). Dengan jelas sekali untuk mengembangkan kecerdasan kinestetik pada anak usia 5 - 6 tahun dapat menggunakan salah satu cara yaitu menari. Dan pembelajaran tari adalah salah satu model pembelajaran yang dapat menarik

perhatian anak, karena gerak sendiri merupakan bagian dari keberadaan alamiah anak. Tari untuk anak - anak berbeda dengan orang dewasa karena karakter fisik dan mentalnya berbeda, oleh karena itu perlu pembelajaran yang tepat yaitu pembelajaran yang benar benar dapat di terima oleh anak usia dini.

Seiring perkembangan jaman dan globalisasi sekarang sudah mulai merambah dunia anak - anak, berbagai jenis tari dari barat pun berkembang di indonesia dan mulai ditiru oleh anak - anak melalui berbagai media. Hingga tari tradisional pun mulai kurang diminati bahkan kurang dikenal, oleh karena itu untuk tetap dapat mempertahankan kebudayaan daerah seperti tari tradisional sekaligus untuk mengembangkan kecerdasan kinestetik bagi anak usia dini, maka perlu dikenalkan tari tradisional kepada anak - anak usia dini, seperti tari Jepen Kalimantan Timur. Gerak dasar tari jepen yang mempunyai gerakan yang sederhana dan dapat di kreasikan sehingga sangat memungkinkan untuk dapat di terima oleh anak usia dini. Dan dilihat dari gerakannya tari jepen dapat merangsang perkembangan motorik kasar anak.

Setyowati (dalam Aris Stiawan 2014 : 56 ) berpendapat ada tiga hal syarat materi tari bagi anak usia dini yaitu sederhana, praktis, dan dinamis. Dari ketiga hal tersebut maka tari jepen kutai sangat memenuhi syarat untuk di perkenalkan pada anak usia dini.Selain itu tari jepen di harapkan bisa membuat ketertarikan tersendiri bagi anak. Untuk anak usia dini kompetensi keterampilan menari lebih di fokuskan pada pengalaman untuk melatih kemampuan sensorik dan motorik, bukan menjadikan anak ahli.

Permasalahan yang akan dibahas dalam penelitian ini menyangkut pengembangan kecerdasan kinestetik anak yang berkenaan dengan pembelajaran menari jepen pada anak, khususnya tari jepen kupu - kupu yang mana gerakan - 
gerakannya telah disesuaikan untuk anak usia 5 - 6 tahun yaitu dengan mengambil beberapa gerakan dasar tari jepen kemudian di kreasikan hingga dapat memenuhi syarat tersebut diatas yaitu sederhana, dinamis, dan praktis. Tari jepen sendiri mempunyai 13 gerakan dasar yang dapat dikreasikan dan divariasikan sesuai dengan kemampuan anak usia dini.

Berdasarkan pengamatan yang dilakukan di Kelompok Bermain Darussakinah 02 Tenggarong Seberang

1. Masih banyak anak yang kesulitan dalam menjaga keseimbangan tubuh serta mengkoordinasikan mata dengan tangan dan kaki dengan musik.

2. Masih banyak anak belum mengenal jenis tari daerah sendiri seperti tari jepen.

10 siswa yang diamati hanya ada sekitar 4 orang siswa yang kecerdasan kinestetiknya sudah mulai berkembang dan untuk tari jepen sendiri dari 10 orang siswa tersebut hanya sekitar 3 orang yang mengenal tari jepen. Melihat kenyataan yang ada penulis akan melakukan Penelitian Tindakan Kelas ( PTK ) dengan judul “Pembelajaran Tari Jepen Dapat Meningkatkan Kecerdasan Kinestetik pada anak usia 5- 6 tahun di Kelompok Bermain Darussakinah 02 Desa Teluk Dalam Kecamatan Tenggarong Seberang.

\section{METODE PENELITIAN}

Penelitian ini menggunakan jenis Penelitian Tindakan Kelas ( PTK ), yaitu pencermatan terhadap kegiatan belajar berupa sebuah tindakan yang sengaja dimunculkan yang terjadi dalam sebuah kelas secara bersama, menurut Suharsini Arikunto dalam Zainal Abidin (2007: 9 ), ada 4 langkah dalam penelitian tindakan kelas diantaranya ialah perencanaan, pelaksanaan tindakan, melakukan pengamatan, dan refleksi.

\section{Tempat Dan Waktu Penelitian}

Penelitian ini dilaksanakan di Kelompok Bermain Darussakinah 02 jalan A.P. Mangkunegara RT. 02 Desa Teluk Dalam, Kecamatan Tenggarong Seberang, Kabupaten Kutai Kartanegara.

Waktu Penelitian Tindakan Kelas ini akan dilaksanakan setiap hari jumat dan sabtu atau dua kali dalam seminggu dan saat jam pelajaran yaitu dari jam 08.00 09.00 wita, dan direncanakan menggunakan 2 siklus, 4 kali pertemuan dalam siklus pertama dan 4 kali pertemuan pada siklus kedua, namun jika penelitian ini belum dapat mencapai hasil yang diharapkan atau belum tuntas pada siklus kedua maka akan dilanjutkan pada siklus berikutnya.

\section{Subjek Penelitian}


Subjek dalam penelitian ini adalah anak - anak di Kelompok Bermain Darussakinah 02 jalan A.P. Mangkunegara RT. 02 Desa Teluk Dalam Kecamatan Tenggarong Seberang, Kabupaten Kutai Kartanegara, yang berjumlah 10 orang, terdiri dari 5 orang anak perempuan dan 5 orang anak laki - laki. Selain itu sebagai sumber informan yaitu sumber informasi lain sebagai pelengkap mengenai pembelajaran tari jepen yaitu teman sejawat ( rekan kerja ).

\section{Prosedur Penelitian}

Pada penelitian ini menggunakan penelitian tindakan kelas ( PTK ), dikatakan dalam satu siklus terdiri dari 4 tahapan ,tahapan - tahapan penelitian dalam masing - masing tindakan terjadi secara berulang yang akhirnya menghasilkan beberapa tindakan, adapun beberapa tahapan tersebut

\section{Penelitian Siklus pertama}

siklus pertama ini terdiri dari beberapa tahapan yaitu tahap perencanaan, aksi atau tindakan, tahap observasi dan evaluasi, dan tahap refleksi.

\section{Tahap Perencanaan}

a) Pertemuan pertama

1) Menyusun rencana pembelajaran (RPPH)

2) Persiapan media pengajaran
3) memperkenalkan gerak dasar tari jepen kupu - kupu yang akan di praktekan oleh guru ( gerakan ke 1-3)

4) anak dibagi menjadi dua kelompok

5) Kemudian anak mengikuti 3 gerak dasar tari yang di contohkan oleh guru secara bersama - sama

6) Kemudian anak di ajak memperaktekkan tari yang mereka pelajari sebelumnya dengan menggunakan tempo

7) Selanjutnya mencoba memperagakan sendiri ( perkelompok ) 3 gerakan tari yang telah diajarkan ( tanpa diiringi musik).

b) Pertemuan kedua

Pertemuan kedua pembelajaran tari jepen sama dengan pertemuan pertama, namun gerakan tari yang di ajarkan akan di tambah yaitu gerakan ke $4-6$.

1) Menyusun rencana pembelajaran (RPPH)

2) Persiapan media pengajaran

3) Memperkenalkan gerak dasar tari jepen kupu - kupu yang akan di praktekan dan menambahkan 3 gerakan lagi yaitu gerak ke $4-6$

4) Anak dibagi menjadi dua kelompok

5) kemudian anak mengikuti gerak dasar tari yang di contohkan oleh guru secara bersama - sama ( gerakkan 1- 6 )

6) kemudian anak diajak memperaktekkan tari yang mereka 
pelajari sebelumnya dengan menggunakan tempo

7) selanjutnya mencoba memperagakan sendiri gerakan tari yang telah diajarkan yaitu gerakan ke $1-6$ tanpa diiringi musik.

Begitu pula pertemuan ke tiga dan pertemuan ke empat pembelajaran gerakan setiap pertemuan akan ditambahkan hingga gerakan yang ke 9 atau terakhir dan untuk pertemuan ke tiga dan ke empat akan mulai menggunakan iringan musik setiap pembelajaran

\section{Aksi Atau Tindakan}

Pada tahap ini ada 3 tahap yaitu pembukaan, kegiatan inti, dan penutup.

a. Pembukaan

Dalam kegiatan pembukaan di mulai dari berbaris di depan kelas, selanjutnya bernyanyi sambil melakukan gerakan untuk melonggarkan otot - otot anak. Anak kemudian dipersilahkan masuk kedalam ruangan dengan tertib dan rapi, kemudian guru melakukan apersepsi yang dimulai dari : mengucap salam, berdoa sebelum belajar, mengabsen murid, menyanyi lagu anak - anak sesuai tema yang akan disampaikan ketika melakukan aktifitas belajar mengajar.

b. Kegiatan inti

Pada kegiatan inti guru menjelaskan kepada anak kegiatan yang akan dilakukan pada hari ini yaitu latihan gerak dasar tari jepen, guru mengambil peran penting dalam mengarahkan dan membimbing anak agar apa yang diajarkan dapat tercapai sesuai dengan apa yang diharapkan, adapun langkah - langkah yang akan dilakukan adalah :

1. Anak di bagi menjadi 2 kelompok, laki - laki dan perempuan saat latihan

2. Memberi penjelasan teknis dan alur pembelajaran dan pelaksanaan

3. Tiap kelompok diberi contoh gerak dan media pembelajaran

4. Selama anak berlatih gerak guru melakukan observasi dan bimbingan

c. Istirahat

Anak - anak mencuci tangan, kemudian membaca doa sebelum makan, makan bersama, membaca doa sesudah makan, kemudian anak bermain di luar.

\section{d. Kegiatan penutup}

Kegiatan penutup ini dilakukan guru adalah diskusi selama kegiatan selama satu hari serta program mengevaluasi pembelajaran, untuk mengetahui tingkat keberhasilannya, guru menggunakan alat evaluasi anak, dan menyuruh anak dalam kelompok memperaktekan semua gerakan yang telah guru berikan pada hari itu.

\section{Tahap Observasi Dan Evaluasi}

Tahap observasi dilakukan pada saat proses belajar mengajar berlangsung, guru 
dapat melakukan observasi terhadap anak dengan menggunakan lembar observasi, atau dapat juga meminta teman sejawat untuk melakukan observasi.

\section{Tahap Refleksi}

Refleksi dilakukan untuk meninjau kembali pembelajaran yang telah di laksanakan, apabila dalam pelaksanaan pembelajaran telah memenuhi kriteria keberhasilan atau masih banyak kelemahan atau kekurangannya, dari hasil rafleksi kegiatan yang telah dilaksanakan akan dijadikan sebagai acuan untuk perbaikan di siklus kedua.

\section{Siklus Kedua}

Pada tahap pelaksanaan siklus II dan seterusnya dilaksanakan dengan melakukan perubahan pada bagian - bagian tertentu yang di dasarkan pada refleksi siklus I sesuai dangan rencana pembelajaran yang telah disusun. Langkah - langkah yang di lakukan pada siklus II dan siklus seterusnya dilakukan sama dengan siklus I, yaitu :

1. Perencanaan

2. Aksi dan tindakan

3. Observasi dan evaluasi

4. Refleksi

Pelaksanaan di setiap siklus dilakukan untuk mengetahui peningkatan dari kecerdasan kinestetik anak.

Teknik Pengumpulan Data

Teknik Observasi ( Pengamatan )
Pengumpulan data di lakukan sendiri oleh peneliti dengan di bantu oleh teman sejawat yaitu guru kelas observasi di lakukan pada anak usia 5-6 tahun di Kelompok Bermain Darussakinah 02.

\section{Dokumentasi}

Teknik dokumentasi yang mendukung berjalannya penelitian ini, foto atau video kegiatan menari berlangsung dan data yang mendukung lainnya untuk di analisis pada tahap awal.

\section{Tes Penampilan}

Tes penampilan dilakukan pada akhir pembelajaran yang dimaksudkan untuk mengevaluasi peningkatan kreativitas pada hasil belajar peserta didik.

\section{Teknik Analisis Data}

Analisis dalam Penelitian Tindakan Kelas ini adalah untuk memperoleh kepastian apakah terjadi perbaiakan, peningkatan, atau perubahan sebagai mana yang diharapkan. Analisis data dan interprestasi hasil analisis dilakukan pada saat proses hingga digunakan lembar observasi untuk mendapatkan data yang akurat pada kemampuan anak, menganalisis data observasi dilakukan dengan analisis proses dan analisis hasil.

Analisis proses adalah analisis terhadap data yang diambil pada saat proses pembelajaran tari berlangsung, sedangkan analisis hasil adalah analisis terhadap data 
yang diambil dari hasil penilaian tes penampilan pada akhir pembelajaran.

\section{Indikator Keberhasilan}

Indikator keberhasilan pada penelitian ini mengacu pada kurikulum 2013 no 146 Tahun 2014. Keberhasilan penelitian kelas ini ditandai dengan adanya perubahan kearah perbaikan adapun keberhasilan dalam penelitian ini apabila hasil kegiatan anak dalam pembelajaran tari jepen terjadi peningkatan mencapai $80 \%$ dari jumlah anak. Kecerdasan kinestetik dengan kriteria Berkembang Sangat Baik ( BSB ), persentase ketuntasan ini dilakukan untuk mempertegas peningkatan kemampuan kinestetik anak dalam pembelajaran tari jepen.

Kriteria Penilaian

BSB : Berkembang Sangat Baik

BSH : Berkembang Sesuai Harapan

MB : Mulai Berkembang

BB : Belum Berkembang Menurut Suharsimi Arikunto dalam Galih Nugraha: 2013) Ketuntasan belajar siswa secara klasikal dihitung dengan rumus :

Ketuntasan klasikal

$$
=\frac{\sum \text { siswayangtuntasbelajar }}{\sum \text { seluruhsiswa }} X 100 \%
$$

Indikator ketuntasan belajar siswa secara klasikal apabila $80 \%$ dari seluruh jumlah siswa dinyatakan tuntas belajar.
Situasi Awal

Penelitian Tindakan Kelas ini dilaksanakan di Kelompok Bermain Darussakinah 02 Jalan A.P. Mangkunegara RT.02 Desa Teluk Dalam Kecamatan Tenggarong Seberang. Kelompok Bermain Darussakinah 02 didirikan sejak tahun 2006, dengan tujuan yaitu memberikan pendidikan pada anak usia dini dengan berbasis agama islam agar menjadi individu yang cerdas, bertaqwa dan berkarakter. Adapun jumlah peserta didik di Kelompok Bermain Darussakinah 02 sebanyak 33 siswa, dan jumlah tenaga pendidik sebanyak 4 orang, yang terdiri dari 1 kepala sekolah dan 3 guru kelas. Kelompok Bermain Darussakinah 02 mempunyai 3 ruang kelas, dan 1 ruang kepala sekolah dan guru.

\section{Hasil Penelitian Dan Analisis Data}

Berdasarkan hasil observasi yang dilakukan terhadap anak usia 5 - 6 tahun di kelompok bermain darussakinah 02 ditemukan bahwa kecerdasan kinestetik anak masih banyak yang belum berkembang, seperti saja

1. Masih banyak anak yang kesulitan dalam menjaga keseimbangan tubuh serta mengkoordinasikan mata dengan tangan dan kaki dengan musik. 
2. Masih banyak anak belum mengenal jenis tari daerah sendiri seperti tari jepen.

Dari hasil pengamatan dan tanya jawab terhadap 10 orang siswa yang diamati dari masing - masing aspek yaitu :

1. Mengkoordinasikan gerakan hanya ada 4 orang mulai berkembang dengan persentase yaitu 4 orang siswa yang mulai berkembang dibagi 10 orang siswa yang diamati dikali $100 \%$ diperoleh hasil $40 \%$, dan yang belum berkembang ( BB ) ada 5 orang dengan persentase yaitu 5 orang siswa yang belum berkembang dibagi 10 orang siswa yang diamati dikali $100 \%$ diperoleh hasil $50 \%$

2. Kemampuan anak dalam menjaga keseimbangan tubuh hanya ada 1 orang yang berkembang sesuai harapan ( $\mathrm{BSH})$ atau dengn persentase 1 orang anak dibagi 10 orang siswa yang diamati dikali $100 \%$ diperoleh hasil $10 \%$, mulai berkembang 4 orang atau dengan persentase 4 orang siswa dibagi 10 orang siswa yang diamati dikali $100 \%$ diperoleh hasil $40 \%$, dan Belum berkembang 5 orang ataudengan persentase 5 orang siswa di bagi 10 orang siswa yang diamati dikali $100 \%$ diperoleh hasil $50 \%$
3. Kemampuan anak dalam menempatkan gerakan dan kekuatan hanya ada 1 orang yang berkembang sesuai harapan ( BSH ) atau dengan persentase 1 orang sisawa dibagi 10 oang siswa yang diamati dikali 100 $\%$ diperoleh hasil $10 \%$, mulai berkembang (MB ) 4 orang atau dengan persentase 4 orang siswa dibagi 10 orang siswa yang diamati dibagi $100 \%$ diperoleh hasil $40 \%$, belum berkembang ( $\mathrm{BB}$ ) 5 orang atau dengan persentase 5 orang siswa dibagi 10 orang siswa yang diamati dikali 100\% diperoleh hasil $50 \%$

4. Kemampuan anak menggabungkan gerakan kaki, tangan, dan meng ekspresikannya ( kelincahan ) hanya ada 4 orang anak yang mulai berkembang ( MB ) atau dengan persentase 4 orang siswa dibagi 10 orang sisawa yang diamati dikali 100 $\%$ diperoleh hasil $40 \%$ dan belum berkembang ( BB ) 6 oarang anak atau dengan persentase 6 orang siswa dibagi 10 orang siswa dikali $100 \%$ maka diperoleh hasil $60 \%$.

Peneliti melakukan penelitian selama 4 kali pertemuan pada siklus 1 dan mendapatkan hasil evaluasi yang berubah berupa peningkatan perkembangan kecerdasan kinestetik peserta didik. Hasil analisis data yang dilaksanakan pada siklus 
I ada 4 kali pertemuan, dengan tema dan sub tema yang berbeda yang terdiri dari kegiatan awal, kegiatan inti dan kegiatan penutup. Dimana siklus 1 pertemuan 1- 4 masih terdapat kekurangan sehingga hasilnya tidak sesuai dengan harapan

\section{SIKLUS I}

1. Koordinasi gerakan hanya ada 7 orang berkembang sesuai harapan (BSH ) atau dengan persentase 7 orang siswa dibagi 10 orang siswa yang diamati dikali $100 \%$ diperoleh hasil $70 \%$, Mulai berkembang ( MB ) 3 orang atau dengan persentase 3 orang siswa di bagi 10 orang siswa yang diamati dikali $100 \%$ maka diperoleh hasil $30 \%$

2. Kemampuan anak dalam menjaga keseimbangan tubuh hanya ada 5 orang yang berkembang sangat baik ( BSB ) atau dengan persentase 5 orang siswa dibagi 10 orang siswa yang diamati dikali $100 \%$ diperoleh hasil $50 \%$, berkembang sesuai harapan ( BSH ) 3 orang atau dengan persentase 3 orang siswa dibagi 10 orang siswa yang diamati dikali $100 \%$ diperoleh hasil $30 \%$, dan mulai berkembang ( MB ) 2 orang atau dengan persentase 2 orang siswa dibagi 10 orang siswa yang diamati dikali 100\% diperoleh hasil $20 \%$
3. Kemampuan anak dalam menempatkan gerakan dan kekuatan hanya ada 6 orang yang berkembang sangat baik ( BSB ) atau dengan persentase 6 orang siswa dibagi 10 orang siswa yang diamati dikali $100 \%$ diperoleh hasil $60 \%$, berkembang sesuai harapan ( $\mathrm{BSH}$ ) 3 orang atau dengan persentase 3 orang siswa dibagi 10 orang siswa yang diamati dikali $100 \%$ diperoleh hasil $30 \%$, mulai berkembang ( MB ) 1 orang atau dengan persentase 1 orang siswa dibagi 10 orang siswa yang diamati dikali 100\% diperoleh hasil $10 \%$

4. Kemampuan anak menggabungkan gerakan kaki, tangan, dan mengekspresikannya ( kelincahan ) hanya ada 5 orang yang berkembang sangat baik ( BSB ) atau dengan persentase 5 orang siswa dibagi 10 orang siswa yang diamati dikali $100 \%$ diperoleh hasil $50 \%$, berkembang sesuai harapan ( $\mathrm{BSH}$ ) 3 orang atau dengan persentase 3 orang siswa dibagi 10 orang siswa yang diamati dikali $100 \%$ diperoleh hasil $30 \%$, mulai berkembang ( MB ) 2 orang atau dengan persentase 2 orang siswa dibagi 10 orang siswa yang diamati dikali 100\% diperoleh hasil $20 \%$ 
Pada siklus I anak masih ada yang kesulitan melakukan gerakan tari. Dari kenyataan ini maka peneliti berkesimpulan untuk melanjutkan penelitian pada siklus 2 .

\section{SIKLUS II}

1. mengkoordinasikan gerakan ada 8 orang berkembang sangat baik ( BSB) atau dengan persentase 8 orang siswa dibagi 10 orang siswa dikali $100 \%$ maka diperoleh hasil $80 \%$, Berkembang sesuai Harapan ( BSH ) ada 1 orang atau dengan persentase 1 orang siswa dibagi 10 orang siswa dikali 100\% maka diperoleh hasil $10 \%$, Mulai berkembang 1 orang atau dengan persentase 1 orang siswa dibagi 10 orang siswa dikali $100 \%$ maka diperoleh hasil $10 \%$ ( MB )

2. Kemampuan anak dalam menjaga keseimbangan tubuh ada 9 orang yang berkembang sangat baik ( BSB ) atau dengan persentase 9 orang siswa dibagi 10 orang siswa dikali $100 \%$ maka diperoleh hasil $90 \%$, berkembang sesuai harapan ( BSH ) 1 orang atau dengan persentase 1 orang siswa dibagi 10 orang siswa dikali 100\% maka diperoleh hasil $10 \%$,

$\begin{array}{llr}\text { 3. Kemampuan } & \text { anak dalam } \\ \text { menempatkan } & \text { gerakan dan }\end{array}$ kekuatan ada 9 orang yang berkembang sangat baik ( BSB ) atau persentase 9 orang siswa dibagi 10 orang siswa dikali $100 \%$ maka diperoleh hasil $90 \%$, berkembang sesuai harapan 1orang atau persentase 1 orang siswa dibagi 10 orang siswa dikali $100 \%$ maka diperoleh hasil $10 \%$,

4. Kemampuan anak menggabungkan gerakan kaki, tangan, dan meng ekspresikannya ( kelincahan ) ada 8 orang yang berkembang sangat baik ( BSB ) atau dengan persentase 8 orang siswa dibagi 10 orang siswa dikali $100 \%$ maka diperoleh hasil $80 \%$, berkembang sesuai harapan ( BSH ) 1 orang atau dengan persentase 1 orang siswa dibagi 10 orang siswa dikali $100 \%$ maka diperoleh hasil $10 \%$, mulai berkembang ( MB ) 1 orang atau dengan persentase 1 orang siswa dibagi 10 orang siswa dikali $100 \%$ maka diperoleh hasil $10 \%$

Hasil penelitian ini ditemukan ternyata dengan latihan gerak dasar tari dapat meningkatkan kecerdasan kinestetik pada anak kelompok usias 5-6 tahun di KB. Darussakinah 02 dengan klasifikasi:

1. Pada kondisi awal menunjukan bahwa hanya ada ada 4 orang anak atau $40 \%$ 
yang kecerdasan kinestetiknya

berkembang sangat baik

2. Pada pelaksanaan siklus I menunjukkan bahwa siswa yang tuntas $50,7 \%$ siswa

3. Pada siklus II siswa yang tuntas sebesar $80,5 \%$ anak

Tabel 1.Hasil pengamatan peningkatankecerdasan kinestetik dari kondisi awal, siklus 1, dan siklus 2

\begin{tabular}{|c|c|c|c|c|c|c|c|}
\hline \multirow{2}{*}{ Tahap } & \multicolumn{3}{|c|}{ Jumlah Siswa } & \multirow{2}{*}{ Yang Tuntas } & \multirow{2}{*}{$\begin{array}{c}\text { Rata } \\
\text { Rersen } \\
\text { tase }\end{array}$} & $\begin{array}{c}\text { Krite } \\
\text { ria }\end{array}$ \\
\cline { 2 - 7 } & 1 & 2 & 3 & 4 & & 4 & \\
\hline $\begin{array}{c}\text { Kondis } \\
\text { i awal }\end{array}$ & 4 & 4 & 4 & 4 & 4 & 0 & MB \\
\hline $\begin{array}{c}\text { Siklus } \\
1\end{array}$ & 5 & 6 & 7 & 5 & 5,7 & $50,7 \%$ & BSH \\
\hline $\begin{array}{c}\text { Siklus } \\
2\end{array}$ & 8 & 9 & 9 & 8 & 8,5 & $80,5 \%$ & BSB \\
\hline
\end{tabular}

Keterangan :

1. Koordinasi mata tangan dan kaki

2. Keseimbangan

3. Kekuatan

4. Kelincahan

Dari tabel diatas dapat dilihat bahwa tingkat kemampuan peserta didik. Meningkatnya kecerdasan kinestetik anak tersebut dikarenakan adanya perbaikanperbaikan berdasarkan kelemahankelemahan yang ada pada siklus pertama. Aspek-aspek kelemahan-kelemahan yang terjadi pada siklus pertama diperbaiki pada siklus kedua sehingga kelemahankelemahan yang ada pada siklus pertama dapat diminimalisir

a) anak yang masih bingung dalam melakukan gerakan tari, b) guru belum menciptakan suasana kelas yang lebih akrab kepada anak,

c) guru kurang memberikan penguatan terhadap setiap gerakan yang dilakukan dalam gerakan tari,

d) belum adanya alat pembelajaran yang digunakan seperti video untuk melihat gerakan tari,

e) ketidakdisiplinan anak pada proses pembelajaran gerak tari.

Selama melaksanakan proses penelitian terhadap 10 anak adalah 8 anak mengalami peningkatan kemampuan gerak dasar tari. Sementara sampai pada pertemuan terakhir di siklus II ada 2 orang anak yang masih belum mencapai indikator keberhasilan yang sudah ditentukan. Persentase keberhasilan kedua anak ini masih di bawah standar indikator keberhasilan $80 \%$.

\section{PENUTUP}

\section{KESIMPULAN}

Dari hasil pembelajaran yang telah dilaksanakan dalam 2 (dua) siklus ini maka ditarik kesimpulan bahwa:

1. Pada pelaksanaan siklus I menunjukkan bahwa $50 \%$ siswa berhasil aktif dan merespon pembelajaran untuk kesiapan menari dengan latihan gerak dasar tari.

2. Pada siklus 2 yang berhasil sebesar $80 \%$ anak sudah dapat melaksanakan gerak tari dengan baik. 
3. Kecerdasan kinestetis anak mampu ditingkatkan melalui tari daerah kutai yaitu tari jepen yang dikreasikan agar lebih menarik yaitu tari jepen kupu kupu dengan cara berkelompok.

\section{SARAN}

1. Untuk lebih meningkatkan kecerdasan kinestetis anak dengan latihan gerak dasar tari, anak atau siswa dikelompok-kelompokkan dan diberikan kegiatan sebelum masuk kelas melakukan gerakan (gerak dasar tari) bersama guru dengan \pm 15 menit.

2. Perlu pengalokasian waktu yang tepat dalam kegiatan pembelajaran agar waktu tidak banyak terbuang percuma.

\section{DAFTAR PUSTAKA}

Abidin, Z. 2007: Penelitian Tindakan Kelas ( PTK ) untuk Guru, Kepala Sekolah, Pengawas, dan Peneliti, Suharsimi Arikunto, ( online ), (http://www.Geocities.com/zai,abidin69/ mypage.html, diakses 6 juli 2007)

Dinas pariwisata Provinsi Daerah Tingkat II Kalimantan Timur, 1996/1997. Inventarisasi Tarian Daerah Kalimantan Timur.

Hamalik, O, 2001: Kurikulum Dan Pembelajaran. Jakarta: Remaja Rosdakarya

Khasanah, I. 2016. Peningkatan Kecerdasan Kinestetik Pada Anak Melalui Tari Tradisional Angguk Di TK. Melati II Galah, Jurnal Pendidikan anak usia dini, 5 (3): $292-300$
Lucy, B. 2009. Mendidik Sesuai Dengan Minat Bakat Anak. Jakarta Selatan: PT. Tangga Pustaka

Meliala, A. 2004. Anak Ajaib, Temukan Dan Kembangkan Keajaiban Anak Anda Melalui Kecerdasan Majemuk. Yogyakarta: Andi

Seefeldt, C \& Wasik,B, A. 2008. Pendidikan Anak Usia Dini Menyiapkan Anak Usia, Tiga, Empat, Dan Lima Tahun Masuk Sekolah. Jakarta: PT. Indeks

Setiawan, A. 2014. Strategi Pembelajaran Tari Anak Usia Dini. Jurnal Pedagogi, ( online ), Surabaya, Volume I Nomor I.

Subini, N. 2011. Mengatasi Kesulitan Belajar Pada Anak. Jakarta: Javelitera

Sujiono, Y, N \& Sujiono, B. 2010. Bermain Kreatif Berbasis Kecerdasan Jamak. Jakarta: PT. Indeks

Yayasan Bengkel Seni Kutai, Tutorial Gerak Dasar Jepen Kutai Kartanegara. ( CDRom ) 